\title{
Reduksi Cacat pada Produk Kaca Lembaran dengan Metode Six Sigma
}

\author{
Milatul Afiah dan Moses Laksono Singgih \\ Departemen Teknik Industri, Fakultas Teknologi Industri, Institut Teknologi Sepuluh Nopember (ITS) \\ e-mail: moseslsinggih@ie.its.ac.id
}

\begin{abstract}
Abstrak-Perusahaan Flat Glass (PFG) merupakan sebuah perusahaan yang memproduksi kaca lembaran dengan proses pengambangan (floating process). Perusahaan ini memiliki tiga jenis produk kaca lembaran (indo clear, panasap dan stopsol). Perusahaan Flat Glass (PFG) berupaya untuk menghasilkan produk bermutu tinggi. Dalam memenuhi permintaan, perusahaan ini memproduksi kaca lembaran di line produksi A1 dan line produksi A2. Namun, proses produksi tersebut masih menghasilkan produk defect yang tinggi. Perusahaan ini telah menetapkan Key Performance Indicator (KPI) mengenai tingkat kecacatan yaitu maksimal sebesar $4.48 \%$ dari jumlah produksi perusahaan. Akan tetapi, tingkat kecacatan masih melebihi target tersebut khususnya di line produksi A1. Jenis kaca Light Green Flat Glass (LNFL) merupakan produk yang dihasilkan dari line produksi A1 dengan tingkat kecacatan melebihi batas KPI. Setelah dilakukan perhitungan sigma level, didapatkan nilai hanya sebesar 3.63 sigma. Dari analisis pareto chart didapatkan tiga jenis defect kritis yaitu cullet defect, chipping defect dan bubble defect. Masing-masing jenis defect kritis tersebut dicari akar permasalahannya menggunakan Root Cause Analysis (RCA) dan dicari akar permasalahan kritis menggunakan Failure Mode and Effect Analysis (FMEA). Kemudian, dilakukan usulan-usulan perbaikan terhadap akar permasalahan kritis. Lalu, dilakukan penentuan target perbaikan serta membandingkan sigma level antara kondisi eksisting dan target perbaikan.
\end{abstract}

Kata Kunci-DMAIC, FMEA, RCA dan Six Sigma.

\section{PENDAHULUAN}

$\mathrm{P}$ ERUSAHAAN Flat Glass (PFG) adalah sebuah perusahaan yang memproduksi kaca lembaran dengan proses pengambangan (floating process). Perusahaan ini memiliki dua buah tungku pembakaran dengan kapasitas produksi maksimal sebesar 300.000 ton per tahun. Terdapat beberapa jenis produk yang dihasilkan yaitu clear, grey, dark grey, blue, dark blue, bronze, dark green, light green, european green, privacy dark grey, heat absorbent glass, privacy dark green dan stopsol (reflective glass). Perusahaan ini berupaya untuk menghasilkan produk bermutu tinggi dan memenuhi Standar Internasional.

Dalam memenuhi permintaan yang datang baik dari pasar nasional maupun pasar internasional, perusahaan melakukan proses produksi untuk menghasilkan kaca lembaran. Proses produksi tersebut dimulai dari proses persiapan bahan baku, proses peleburan bahan baku, proses pembentukan kaca lembaran sampai dengan proses pengemasan kaca lembaran.

Proses produksi kaca lembaran tersebut masih menghasilkan produk cacat (defect). Persentase jumlah produk defect yang dihasilkan dari proses produksi tersebut masih tinggi. Padahal perusahaan telah menetapkan Key Performance Indicator (KPI) mengenai tingkat kecacatan (defect rate) yaitu sebesar $4.48 \%$ dari jumlah produksi. Sehingga, diharapkan proses produksi tersebut menghasilkan produk cacat (defect) yang tidak melebihi batas KPI tersebut. Tabel 1 menunjukkan jumlah produk defect kaca lembaran pada bulan Januari sampai Maret 2017.

Tabel 1

Jumlah Produk Defect Kaca Lembaran Januari - Maret 2017

\begin{tabular}{|c|c|c|c|c|}
\hline $\begin{array}{c}\text { Line } \\
\text { Produksi }\end{array}$ & Bulan & $\begin{array}{c}\text { Jumlah } \\
\text { Produksi Kaca }\end{array}$ & $\begin{array}{c}\text { Jumlah Produk } \\
\text { Defect }\end{array}$ & $\begin{array}{l}\text { Defect } \\
\text { Rate }\end{array}$ \\
\hline \multirow{3}{*}{ A1 } & Jan-17 & 180,123 & 9,186 & $5.10 \%$ \\
\hline & Feb-17 & 185,209 & 9,131 & $4.93 \%$ \\
\hline & Mar-17 & 239,279 & 14,811 & $6.19 \%$ \\
\hline \multirow{3}{*}{ A2 } & Jan-17 & 277,978 & 11,230 & $4.04 \%$ \\
\hline & Feb-17 & 240,722 & 8,449 & $3.51 \%$ \\
\hline & Mar-17 & 231,271 & 4,255 & $1.84 \%$ \\
\hline
\end{tabular}

Sumber : Data Perusahaan

Berdasarkan Tabel 1, dapat dilihat bahwa setiap proses produksi yang dilakukan di line produksi A1 dan line produksi A2 selalu menghasilkan produk defect. Namun, produk defect yang dihasilkan di line produksi A1 memiliki persentase yang jauh lebih besar dibandingkan dengan line produksi A2.

Pada bulan Januari 2017, dihasilkan persentase produk defect sebanyak $5.10 \%$ di line produksi A1 dari keseluruhan jumlah produk kaca lembaran sebanyak 180,123. Lalu, pada bulan Februari 2017, di line produksi A1 dihasilkan jumlah produk kaca lembaran yaitu sebesar 185,209 dengan persentase produk defect sebesar $4.93 \%$. Kemudian, pada bulan Maret, dihasilkan persentase produk defect sebanyak 6.19\% di line produksi A1 dari keseluruhan jumlah produk kaca lembaran sebanyak 239,279. Sedangkan di line produksi A2 dihasilkan persentase $4.04 \%, 3.51 \%$ dan $1.84 \%$ untuk bulan Januari sampai Maret 2017. Sehingga dapat dikatakan bahwa persentase produk defect di line produksi A1 lebih besar daripada persentase produk defect di line produksi A2.

Adapun jenis cacat (defect) yang terjadi pada produk kaca lembaran antara lain yaitu adanya gelembung udara yang terperangkap di dalam kaca, butiran kaca yang menempel di permukaan kaca dan batu yang terdapat di dalam kaca lembaran. Selain itu, jenis defect pada kaca lembaran yaitu adanya gumpil pada sudut kaca dan goresan pada permukaan kaca.

Beberapa produk defect tersebut dapat dikenakan proses pengerjaan ulang (rework). Namun, pada kenyataannya produk 
cacat (defect) yang dihasilkan akan dipisahkan dan dijadikan sebagai bahan campuran untuk proses produksi selanjutnya. Tingginya jumlah produk cacat tentunya sangat merugikan perusahaan karena biaya proses produksi kaca lembaran tersebut akan sia-sia. Dengan demikian, perlu adanya perbaikan pada proses produksi untuk menurunkan jumlah cacat yang ada pada line produksi A1 di perusahaan tersebut.

Perusahaan ini telah berupaya menjaga kualitas kaca lembaran. Hal itu ditunjukkan dengan adanya penggunaan control chart telah diterapkan untuk mengontrol proses produksi kaca lembaran. Namun, perusahaan ini belum menerapkan Six Sigma di dalam proses produksi.

Six Sigma merupakan suatu metode yang digunakan dalam pengendalian kualitas. Menurut Yang \& El Haik, Six Sigma adalah metodologi yang dapat digunakan oleh perusahaan untuk meningkatkan kapabilitas proses bisnisnya [7]. Tujuan utama dari penerapan metode Six Sigma yaitu mengurangi variasi yang besar pada proses produksi. Metode Six Sigma mampu memberikan dampak positif dalam mereduksi jumlah defect kaca lembaran. Tools yang digunakan dalam upaya mereduksi defect adalah Define, Measure, Analyze, Improvement, Control (DMAIC Six Sigma), Supplier Input Process Output Customer (SIPOC), Pareto Chart, Root Cause Analysis (RCA), dan Failure Mode and Effect Analysis (FMEA).

\section{METODE PENELITIAN}

\section{A. Tahap Pengumpulan dan Pengolahan Data}

\section{Define}

Pada tahap define dilakukan penelitian terhadap kondisi eksisting perusahaan dengan cara observasi secara langsung ke perusahaan untuk mengetahui proses produksi, pencapaian serta performansi proses di perusahaan tersebut. Kemudian, dilakukan penggambaran aktivitas-aktivitas produksi menggunakan bagan SIPOC untuk mengidentifikasi semua elemen yang relevan dalam proses perbaikan. Lalu, dilakukan identifikasi jenis cacat pada produk kaca lembaran.

\section{Measure}

Pada tahap measure dilakukan perhitungan nilai performansi awal (DPMO, Nilai Sigma). Selain itu, dilakukan identifikasi jenis cacat yang sering terjadi menggunakan pareto chart.

\section{B. Tahap Analisis dan Interpretasi Data}

\section{Analyze}

Pada tahap analyze, dilakukan analisis terhadap cacat yang sering terjadi pada produk. Analisis tersebut berkaitan dengan penyebab munculnya cacat serta dampak yang ditimbulkan terhadap kualitas produk. Kemudian, mencari akar permasalahan menggunakan Root Cause Analysis (RCA) dari setiap jenis cacat yang sering muncul. Lalu, didapatkan akar permasalahan kritis menggunakan FMEA.

\section{Improve}

Pada tahap improve, dilakukan pembuatan alternatifalternatif perbaikan yang sesuai dengan akar permasalahan kritis dari tiap jenis defect. Diharapkan usulan terbaik tersebut dapat menjadi masukan untuk perusahaan dalam melakukan peningkatan performansi perusahaan. Lalu, dilakukan penerapan target perbaikan dari alternatif yang telah diusulkan. Nantinya akan dilakukan perbandingan nilai sigma dari target perbaikan dan kondisi eksisting.

\section{PENGUMPULAN DAN PENGOLAHAN DATA}

\section{A. Define}

\section{Identifikasi Produk Amatan}

PFG menghasilkan produk kaca lembaran di line produksi A1 dan A2. Jenis kaca yang digunakan sebagai objek amatan adalah produk kaca lembaran yang diproduksi di line produksi A1 (LNFL). Alasan pemilihan objek amatan tersebut karena pada line produksi A1 menghasilkan persentase jumlah defect yang lebih tinggi dibandingkan line produksi A2. Misalnya, pada bulan Januari - Maret 2017 dihasilkan persentase jumlah produk defect yang jauh lebih besar pada line produksi A1. Gambar 1 menunjukkan grafik jumlah produk defect kaca lembaran pada bulan Januari 2017 sampai Maret 2017.

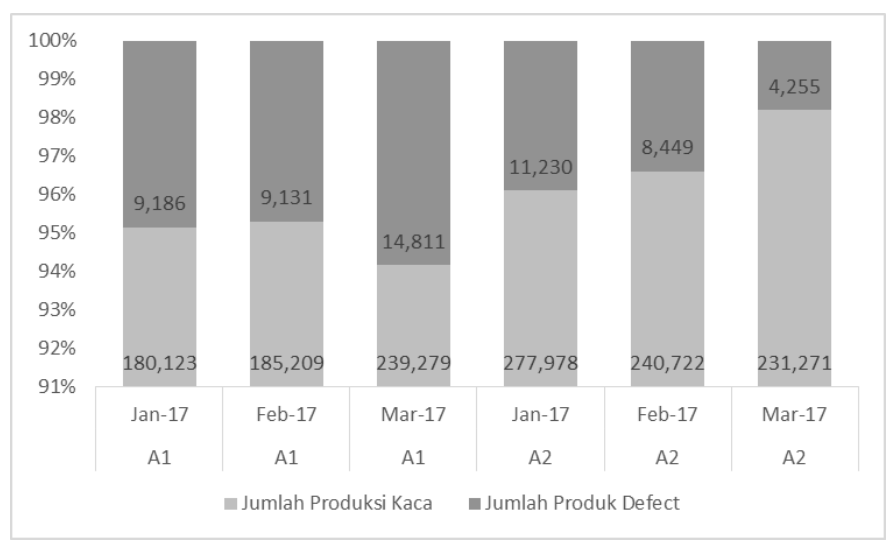

Gambar 1. Grafik Jumlah Produk Defect Kaca Lembaran Januari-Maret 2017.

Berdasarkan Gambar 1, dapat dilihat bahwa setiap proses produksi yang dilakukan di line produksi A1 dan line produksi A2 selalu menghasilkan produk defect. Namun, produk defect yang dihasilkan di line produksi A1 memiliki persentase yang jauh lebih besar dibandingkan produk defect yang dihasilkan di line produksi A2.

Line produksi A1 pada bulan Januari, Februari dan Maret 2017 dihasilkan persentase produk defect sebanyak 5.10\%, $4.93 \%$ dan $6.19 \%$. Sedangkan di line produksi A2 dihasilkan persentase produk defect $4.04 \%, 3.51 \%$ dan $1.84 \%$ untuk bulan Januari-Maret 2017. Sehingga dapat dikatakan bahwa persentase produk defect di line produksi A1 lebih besar daripada persentase produk defect di line produksi A2.

Produk kaca lembaran pada line produksi A1 tersebut memiliki Key Performance Indicator (KPI) mengenai tingkat kecacatan (defect rate) yaitu sebesar $4.48 \%$ dari jumlah produksi. Akan tetapi pada hasil proses produksi tersebut masih sering melewati batas KPI yang telah ditetapkan. Oleh karena itu, perlu dilakukan perbaikan pada line produksi A1.

\section{Penggambaran SIPOC}

Menurut Pyzdek \& Keller, SIPOC merupakan suatu metode yang digunakan dalam manajemen dan peningkatan proses [1]. SIPOC digunakan untuk menggambarkan aktivitas-aktivitas 
proses produksi pada line produksi A1. Aktivitas-aktivitas proses produksi perlu digambarkan untuk mengetahui keterkaitan antara satu proses ke proses lainnya. Selain itu, dapat diketahui jenis defect yang dihasilkan dari proses-proses yang ada.

Dilakukan identifikasi dari kelima elemen SIPOC yang didapatkan dari hasil wawancara dengan expert di divisi produksi. Berikut merupakan bagan SIPOC pada proses produksi kaca lembaran di line produksi A1 untuk produk kaca LNFL.

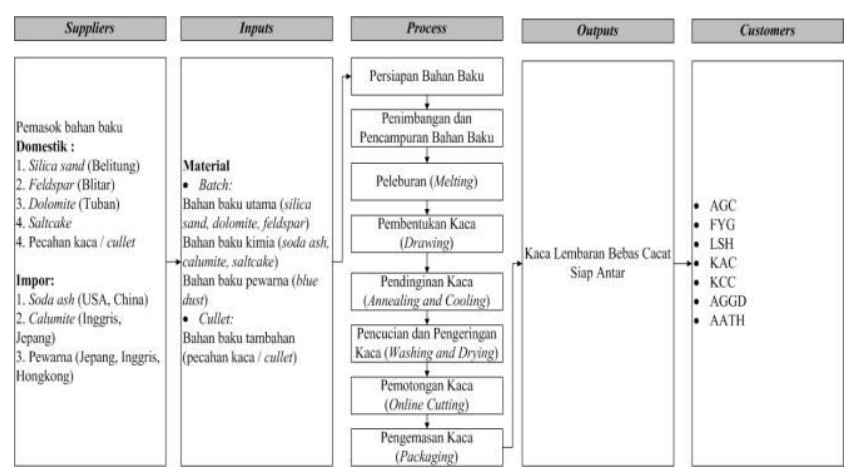

Gambar 2. Bagan SIPOC pada Seluruh Proses Produksi Kaca Lembaran.

\section{B. Measure}

1. Identifkasi Critical to Quality (CTQ) pada Kaca Lembaran

Setelah dilakukan identifikasi defect yang berpengaruh terhadap kualitas produk maka dilakukan identifikasi CTQ pada kaca lembaran. Tabel 2 menunjukkan jumlah defect produk kaca lembaran berdasarkan CTQ potensial.

Tabel 2.

\begin{tabular}{ccc} 
& Jumlah defect produk LNFL berdasarkan CTQ potensial \\
\hline \hline No & Jenis Defect & Jumlah Defect \\
\hline 1 & Bubble & 27 \\
2 & Cullet & 72 \\
3 & Inclusion & 5 \\
4 & Chipping & 49 \\
5 & Scratch & 5 \\
\hline & Total & 158
\end{tabular}

Sumber: Data Perusahaan

Selanjutnya, dari data-data tersebut diolah menggunakan pareto chart agar didapatkan persentase kontibusi tiap jenis defect terhadap keseluruhan jenis defect yang ada pada sistem produksi kaca lembaran. Gambar 3 menunjukkan pareto chart jenis defect yang terjadi pada kaca LNFL.

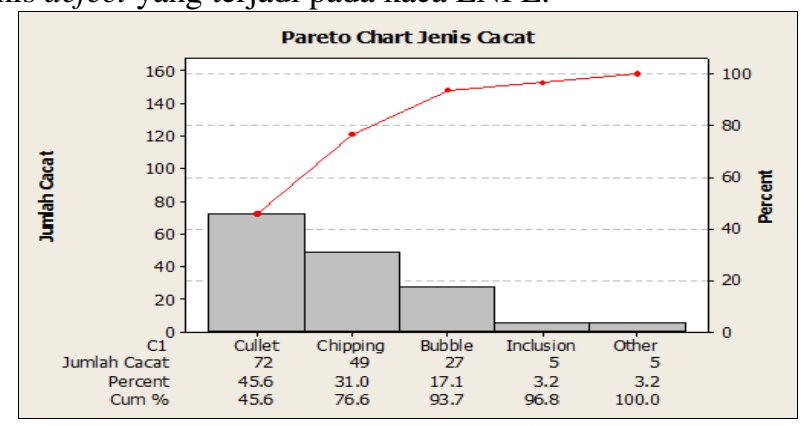

Gambar 3. Pareto Chart Jenis Defect yang Terjadi Pada Kaca LNFL.
Berdasarkan prinsip pareto chart maka defect yang akan dilakukan perbaikan adalah defect yang mempengaruhi sekitar $80.0 \%$ dari keseluruhan defect yang ada. Sehingga berdasarkan Gambar 3, jenis-jenis defect yang perlu diperbaiki yaitu cullet defect mempengaruhi sebesar 45.6\%, chipping defect mempengaruhi $31.0 \%$ dan bubble defect mempengaruhi $17.1 \%$ dari total defect proses produksi kaca LNFL.

2. Pengukuran Kapabilitas Proses Awal Produksi Kaca Lembaran (Nilai Sigma dan DPMO)

Kapabilitas proses merupakan kemampuan suatu proses untuk menghasilkan suatu produk yang sesuai dengan spesifikasi dari konsumen. Kinerja dari proses produksi kaca lembaran dapat diketahui jika nilai sigma diketahui. Selain itu, nilai sigma dapat digunakan sebagai acuan untuk dilakukannya perbaikan (improvement) pada sistem.

Menurut Montgomery, Defects per Million Opportunities (DPMO) adalah sejumlah peluang terjadinya cacat dari sejuta kesempatan yang ada [2]. Rumus untuk menghitung nilai DPMO sebagai berikut.

$$
\begin{aligned}
\text { Tingkat Cacat } & =\frac{\text { Jumlah Produk Cacat }}{\text { Jumlah produksi }} \\
\text { DPO } & =\frac{\text { Tingkat Cacat }}{\text { Banyak CTQ }} \\
\text { DPMO } & =\text { DPO x } 1,000,000
\end{aligned}
$$

Tabel 3 menunjukkan jumlah produksi dan jumlah defect yang akan dihitung nilai sigma dan DPMO.

Tabel 3.

Jumlah Produksi dan Jumlah Defect Kaca LNFL

\begin{tabular}{clc}
\hline \hline No & \multicolumn{1}{c}{ Data yang Diperlukan } & Keterangan \\
\hline 1 & Jumlah produksi & 185,209 \\
2 & Jumlah produk defect & 9,131 \\
3 & $\begin{array}{l}\text { Banyaknya CTQ potensial yang dapat } \\
\text { menyebabkan defect }\end{array}$ & 3 \\
\hline \hline
\end{tabular}

Berikut merupakan perhitungan nilai DPMO dan nilai sigma.

$\begin{aligned} \text { Tingkat Cacat } & =\frac{9,131}{185,209} \\ & =0.0493 \\ \text { DPO } & =\frac{0.0493}{3} \\ \text { DPMO } & =0.016434 \\ & =0.016434 \times 1,000,000 \\ & =16,434\end{aligned}$

Dari perhitungan yang telah dilakukan dapat diketahui bahwa nilai DPMO dari proses produksi kaca lembaran adalah sebesar 16,434. Dengan demikian, nilai sigma dihitung menggunakan kalkulator sigma dengan memasukkan nilai DPMO [3]. Sehingga dihasilkan nilai sigma sebesar 3.63 dengan CTQ sebanyak tiga jenis.

Menurut perusahaan, nilai sigma tersebut masih cukup rendah. Sehingga, perlu adanya perbaikan dengan cara mengurangi jumlah defect pada produk kaca lembaran. 


\section{ANALISIS DAN INTERPRETASI DATA}

\section{A. Analyze}

1. Analisis terhadap Defect Kritis pada Kaca LNFL

Berdasarkan penentuan defect kritis maka didapatkan tiga jenis defect yang menjadi Critical to Quality dari produk kaca LNFL yaitu cullet defect, chipping defect dan bubble defect.

Cullet Defect adalah jenis defect berupa butiran kaca yang menempel di permukaan kaca. Defect ini dapat terjadi karena tekanan yang diberikan pada proses pemotongan kaca yang tidak sempurna sehingga menghasilkan butiran kaca terlepas dan menempel dipermukaan kaca. Selain itu, penggunaan cutter yang kurang tajam dapat menimbulkan butiran kaca yang menempel pada permukaan kaca. Jenis defect ini sering terjadi di seksi pemotongan kaca. Jenis defect ini termasuk ke dalam defect kritis karena frekuensi munculnya lebih tinggi daripada jenis defect lainnya.

Chipping Defect adalah jenis defect berupa gumpil pada sudut kaca. Defect ini dapat terjadi saat proses pemotongan kaca yang kurang sempurna. Jenis defect ini merupakan defect kritis karena frekuensi kemunculan yang tinggi.

Bubble Defect adalah jenis defect berupa gelembung yang terperangkap di dalam kaca. Defect ini dapat terjadi karena berbagai faktor. Salah satunya yaitu temperatur yang rendah pada proses peleburan (melting) sehingga gelembung tidak dapat keluar dari molten glass. Jenis defect ini terjadi pada proses peleburan (melting process). Namun, kesalahan pada proses sebelumnya yaitu proses penimbangan dapat mengakibatkan kemunculan bubble defect. Jenis defect ini termasuk defect kritis karena berpengaruh besar terhadap kualitas kaca lembaran.

2. Root Cause Analysis (RCA)

Menurut Mann, Root Cause Analysis (RCA) merupakan sebuah basic tools yang fokus mengeliminasi penyebab dari permasalahan [4]. Salah satu tools RCA adalah 5 why.

Pada penelitian ini RCA dilakukan untuk cullet defect, chipping defect dan bubble defect. Analisis menggunakan RCA dilakukan dengan cara diskusi dengan salah satu expert (Assistant Section Chief) di divisi produksi yang memiliki pengetahuan yang mendalam terkait proses pembuatan kaca.

Dalam menentukan akar permasalahan dari jenis defect tersebut, maka akan digunakan akar permasalahan dari why yang paling akhir. Tabel 4, Tabel 5 dan Tabel 6 menunjukkan akar permasalahan dari tiga jenis defect tersebut.

Tabel 4.

RCA Cullet Defect

\begin{tabular}{|c|c|c|}
\hline Permasalahan & Akar Masalah & Keterangan \\
\hline \multirow{2}{*}{$\begin{array}{l}\text { Proses } \\
\text { pemotongan } \\
\text { (cutting) kurang } \\
\text { sempurna }\end{array}$} & $\begin{array}{l}\text { Kurangnya pengetahuan operator } \\
\text { terkait setting mesin cutting }\end{array}$ & Why 4 \\
\hline & $\begin{array}{l}\text { Perkiraan usia pakai cutter pada } \\
\text { mesin cutting kurang tepat }\end{array}$ & Why 4 \\
\hline
\end{tabular}

Tabel 5.

RCA Chipping Defect

Permasalahan Akar Masalah $\quad$ Keterangan

\begin{tabular}{|c|c|c|}
\hline $\begin{array}{l}\text { Proses pemotongan } \\
\text { (cutting) kurang } \\
\text { sempurna }\end{array}$ & $\begin{array}{l}\text { Kurangnya pengetahuan } \\
\text { operator terkait setting mesin } \\
\text { cutting }\end{array}$ & Why 4 \\
\hline & $\begin{array}{c}\text { Tabel } 6 . \\
\text { RCA Bubble Defect }\end{array}$ & \\
\hline Permasalahan & Akar Masalah & Keterangan \\
\hline \multirow{5}{*}{$\begin{array}{l}\text { Temperatur peleburan } \\
\text { terlalu rendah } \\
\left.\text { (kurang dari } 1400^{\circ} \mathrm{C}\right)\end{array}$} & $\begin{array}{l}\text { Alat pengukur temperatur } \\
\text { sudah mencapai life time }\end{array}$ & Why 3 \\
\hline & $\begin{array}{l}\text { Kurangnya penjadwalan } \\
\text { kalibrasi alat ukur }\end{array}$ & Why 3 \\
\hline & $\begin{array}{l}\text { Kurangnya kontrol pada } \\
\text { proses produksi sebelumnya }\end{array}$ & Why 4 \\
\hline & $\begin{array}{l}\text { Kurangnya kontrol terkait } \\
\text { jumlah 2nd air ratio yang } \\
\text { diperlukan }\end{array}$ & Why 4 \\
\hline & $\begin{array}{l}\text { Kurangnya pengetahuan } \\
\text { operator atau engineer terkait } \\
\text { penggunaan jenis tip burner } \\
\text { yang sesuai dengan flow }\end{array}$ & Why 4 \\
\hline \multirow{2}{*}{$\begin{array}{l}\text { Flow bubbler terlalu } \\
\text { cepat (lebih dari } 7-12 \\
\text { liter/menit) }\end{array}$} & $\begin{array}{l}\text { Kurangnya pengetahuan } \\
\text { operator atau engineer terkait } \\
\text { pengaturan gate blanket } \\
\text { feeder }\end{array}$ & Why 4 \\
\hline & $\begin{array}{l}\text { Minimnya referensi } \\
\text { operation terkait pengaturan } \\
\text { gate blanket feeder yang } \\
\text { tepat }\end{array}$ & Why 4 \\
\hline $\begin{array}{l}\text { Kekurangan } \mathrm{SO}_{2} \text { yang } \\
\text { membantu pelepasan } \\
\text { gelembung udara } \\
(0.18 \% \text { dari total } \\
\text { produksi) }\end{array}$ & $\begin{array}{l}\text { Kesalahan dalam setting } \\
\text { formula batch }\end{array}$ & Why 3 \\
\hline \multirow{2}{*}{$\begin{array}{l}\text { Batu tahan api yang } \\
\text { memiliki kerapatan } \\
\text { rendah }\end{array}$} & $\begin{array}{l}\text { Kurangnya pengetahuan akan } \\
\text { spesifikasi batu furnace }\end{array}$ & Why 2 \\
\hline & $\begin{array}{l}\text { Kebijakan perusahaan dalam } \\
\text { melakukan cost saving }\end{array}$ & Why 2 \\
\hline $\begin{array}{l}\text { Pemakaian cullet } \\
\text { yang berlebih (lebih } \\
\text { dari } 64 \% \text { dari total } \\
\text { produksi) }\end{array}$ & $\begin{array}{l}\text { Kurangnya ketelitian operator } \\
\text { dalam penimbangan dan } \\
\text { input data pemakaian } \text { cullet }\end{array}$ & Why 4 \\
\hline $\begin{array}{l}\text { Kurangnya pemberian } \\
\text { waktu tinggal di } \\
\text { tungku (pull konversi } \\
\text { lebih dari } 510 \mathrm{~T} / \mathrm{D} \text { ) }\end{array}$ & $\begin{array}{l}\text { Kurangnya pengetahuan } \\
\text { operator terkait setting mesin } \\
\text { drawing }\end{array}$ & Why 5 \\
\hline $\begin{array}{l}\text { Kelebihan } \\
\text { penggunaan saltcake } \\
\text { (lebih dari } 28 \mathrm{Kg} / \mathrm{mix} \text { ) }\end{array}$ & $\begin{array}{l}\text { Kesalahan perhitungan } \\
\text { jumlah kebutuhan saltcake }\end{array}$ & Why 2 \\
\hline $\begin{array}{l}\text { Adanya benda asing } \\
\text { seperti NiS dan } \mathrm{Si} \\
\text { yang masuk ke dalam } \\
\text { molten glass } \\
\end{array}$ & $\begin{array}{l}\text { Pengawasan yang kurang } \\
\text { ketat terkait kondisi operasi } \\
\text { dan peralatan }\end{array}$ & Why 2 \\
\hline
\end{tabular}

3. Failure Mode and Effect Analysis (FMEA)

FMEA merupakan sebuah metode yang sangat penting untuk mengeliminasi potential failures [7]. Menurut Singgih, FMEA digunakan untuk mendapatkan akar permasalahan kritis yang diperoleh dengan cara mengurutkan nilai Risk Priority Number (RPN) dari tiap jenis defect [5]. Nilai RPN tersebut dihasilkan dari perkalian antara tingkat keparahan akar masalah (severity), frekuensi akar permasalahan (occurance) dan kesulitan untuk melakukan deteksi terhadap gejala defect yang ditimbulkan dari akar permasalahan (detection) [6].

Penilaian severity $(\mathrm{S})$, occurance $(\mathrm{O})$ dan detection (D) didasarkan pada brainstorming yang dilakukan dengan tujuh orang expert di bagian produksi melalui kuesioner FMEA. 
Tujuh orang expert di bagian produksi tersebut adalah beberapa orang Section Chief dan beberapa orang Assistant Section Chief. Expert-expert tersebut memiliki pengetahuan lebih terkait proses produksi kaca lembaran di perusahaan tersebut.

Kriteria dalam penilaian SOD tersebut mengacu pada definisi skala SOD menurut The Basic of FMEA oleh McDermott yang telah disesuaikan dengan kondisi perusahaan. Tabel 7, Tabel 8 dan Tabel 9 menunjukkan rekap nilai RPN dari masing-masing jenis defect pada kaca lembaran LNFL.

Tabel 7.

RPN Cullet Defect

\begin{tabular}{lcccc}
\multicolumn{1}{c}{ Akar Permasalahan } & S & O & D & RPN \\
\hline \hline $\begin{array}{l}\text { Kurangnya pengetahuan operator terkait setting } \\
\text { mesin } \text { cutting }\end{array}$ & 6 & 4 & 4 & 96 \\
\hline $\begin{array}{l}\text { Perkiraan usia pakai } \text { cutter } \text { pada mesin } \text { cutting } \\
\text { kurang tepat }\end{array}$ & 5 & 3 & 4 & 60 \\
\hline \hline
\end{tabular}

Tabel 8.

RPN Chipping Defect

\begin{tabular}{lllll}
\hline \multicolumn{1}{c}{ Akar Permasalahan } & S & O & D & RPN \\
& & & & \\
\hline $\begin{array}{l}\text { Kurangnya pengetahuan operator terkait setting } \\
\text { mesin cutting }\end{array}$ & 5 & 3 & 3 & 45 \\
\hline \hline
\end{tabular}

Tabel 9.

RPN Bubble Defect

\begin{tabular}{|c|c|c|c|c|}
\hline Akar Permasalahan & $\mathrm{S}$ & $\mathrm{O}$ & $\mathrm{D}$ & RPN \\
\hline $\begin{array}{l}\text { Alat pengukur temperatur sudah mencapai life } \\
\text { time }\end{array}$ & 4 & 2 & 3 & 24 \\
\hline Kurangnya penjadwalan kalibrasi alat ukur & 5 & 2 & 3 & 30 \\
\hline $\begin{array}{l}\text { Kurangnya kontrol pada proses produksi } \\
\text { sebelumnya }\end{array}$ & 4 & 3 & 4 & 48 \\
\hline $\begin{array}{l}\text { Kurangnya kontrol terkait jumlah 2nd air ratio } \\
\text { yang diperlukan }\end{array}$ & 6 & 3 & 2 & 36 \\
\hline $\begin{array}{l}\text { Kurangnya pengetahuan operator atau engineer } \\
\text { terkait penggunaan jenis tip burner yang sesuai } \\
\text { dengan flow }\end{array}$ & 5 & 4 & 3 & 60 \\
\hline $\begin{array}{l}\text { Kurangnya pengetahuan operator atau engineer } \\
\text { terkait pengaturan gate blanket feeder }\end{array}$ & 4 & 4 & 3 & 48 \\
\hline $\begin{array}{l}\text { Minimnya referensi operation terkait } \\
\text { pengaturan gate blanket feeder yang tepat }\end{array}$ & 4 & 3 & 4 & 48 \\
\hline Kesalahan dalam setting formula batch & 6 & 3 & 3 & 54 \\
\hline $\begin{array}{l}\text { Kurangnya pengetahuan akan spesifikasi batu } \\
\text { furnace }\end{array}$ & 4 & 3 & 5 & 60 \\
\hline $\begin{array}{l}\text { Kebijakan perusahaan dalam melakukan cost } \\
\text { saving }\end{array}$ & 4 & 3 & 3 & 36 \\
\hline $\begin{array}{l}\text { Kurangnya ketelitian operator dalam } \\
\text { penimbangan dan input data pemakaian cullet }\end{array}$ & 6 & 3 & 3 & 54 \\
\hline $\begin{array}{l}\text { Kurangnya pengetahuan operator terkait setting } \\
\text { mesin drawing }\end{array}$ & 5 & 3 & 4 & 60 \\
\hline $\begin{array}{l}\text { Kesalahan perhitungan jumlah kebutuhan } \\
\text { saltcake }\end{array}$ & 6 & 3 & 3 & 54 \\
\hline $\begin{array}{l}\text { Pengawasan yang kurang ketat terkait kondisi } \\
\text { operasi dan peralatan }\end{array}$ & 7 & 3 & 4 & 84 \\
\hline
\end{tabular}

\section{B. Improve}

1. Usulan alternatif terhadap akar permasalahan dengan RPN tertinggi

Selanjutnya, ditentukan usulan alternatif solusi dari tiap jenis defect. Alternatif solusi tersebut akan dijadikan sebagai masukan ke perusahaan untuk mengatasi permasalahan terkait defect di line produksi A1.

Tabel 10 menunjukkan alternatif solusi dari tiap jenis defect pada kaca lembaran LNFL.

Tabel 10.

Alternatif Solusi dari Tiap Jenis Defect

$\begin{array}{ccc}\text { Jenis } & \text { Akar Permasalahan } & \text { Alternatif Solusi } \\ \text { Defect } & \text { dengan RPN } & \\ & \text { Tertinggi } & \end{array}$

Kurangnya

Cullet pengetahuan operator

Defect terkait setting mesin cutting

\section{Kurangnya}

Chippin pengetahuan operator

$g$ Defect

terkait setting mesin cutting

\section{Bubble}

Defect
Pengawasan yang kurang ketat terkait kondisi operasi dan peralatan
Selektif dalam merekrut operator mesin cutting dan pemberian training secara berkala

\section{Target Perbaikan}

Setelah dilakukan usulan alternatif solusi maka akan ditetapkan target perbaikan. Target perbaikan didapatkan dari hasil diskusi dengan salah satu expert di divisi produksi. Perusahaan menetapkan target perbaikan untuk penurunan jumlah defect yaitu cullet defect sebesar 50\%, chipping defect sebesar 50\% dan bubble defect sebesar 40\%. Hal tersebut telah mempertimbangkan resources yang dimiliki perusahaan. Tabel 11 merupakan target perbaikan pada proses produksi kaca lembaran lembaran LNFL di line produksi A1.

Tabel 11.

Target Perbaikan Performansi

\begin{tabular}{cccc}
\hline Jenis Cacat & $\begin{array}{c}\text { Kontribusi } \\
\text { terhadap Total } \\
\text { Defect }\end{array}$ & $\begin{array}{c}\text { Target } \\
\text { Perbaikan }\end{array}$ & $\begin{array}{c}\text { Target } \\
\text { Pengurangan } \\
\text { Jumlah Defect }\end{array}$ \\
\hline $\begin{array}{c}\text { Cullet Defect } \\
\text { Chipping Defect }\end{array}$ & $\begin{array}{c}45.6 \% \\
\text { Bubble Defect }\end{array}$ & $50 \%$ & $22.8 \%$ \\
Total Target Pengurangan Jumlah Defect & $6.0 \%$ \\
\hline
\end{tabular}

Berdasarkan Tabel 11, didapatkan total target pengurangan jumlah defect yaitu sebesar $45.1 \%$. Sehingga dari jumlah produksi 185,209 dengan jumlah defect eksisting sebanyak 9,131, didapatkan target perbaikan jumlah defect sebesar 5,013 .

Selanjutnya akan dilakukan perhitungan target perbaikan sigma level dan target perbaikan DPMO. Tabel 12 menunjukkan data yang akan digunakan untuk menghitung target perbaikan nilai sigma dan target perbaikan DPMO.

Tabel 12.

Jumlah Produksi dan Target Perbaikan Jumlah Defect Kaca LNFL

\begin{tabular}{ccc}
\hline No & Data yang Diperlukan & Keterangan \\
\hline 1 & Jumlah produksi & 185,209
\end{tabular}




\begin{tabular}{llc}
2 & Target perbaikan jumlah produk defect & 5,013 \\
3 & $\begin{array}{l}\text { Banyaknya CTQ potensial yang dapat } \\
\text { menyebabkan defect }\end{array}$ & 3 \\
\hline
\end{tabular}

Target perbaikan nilai DPMO didapatkan dari perhitungan menggunakan rumus yang sama dengan perhitungan nilai DPMO awal. Berikut merupakan perhitungan target perbaikan nilai DPMO.

$\begin{array}{ll}\text { Tingkat Cacat } & =\frac{5,013}{185,209} \\ & =0.027 \\ \text { DPO } & =\frac{0.027}{3} \\ & =0.009022 \\ \text { DPMO } & =0.009022 \times 1,000,000 \\ & =9,022\end{array}$

Didapatkan target perbaikan nilai DPMO sebesar 9,022. Lalu, target perbaikan nilai sigma didapatkan dari perhitungan menggunakan kalkulator sigma dengan input nilai DPMO, sehingga didapatkan nilai sebesar 3.86 sigma. Sedangkan kondisi eksisting memiliki nilai DPMO sebesar 16,434 dan nilai sigma sebesar 3.63 sigma. Jadi, diharapkan akan terjadi peningkatan nilai sigma sebesar 0.23 sigma.

\section{KESIMPULAN}

Berikut merupakan kesimpulan yang bisa diambil dari penelitian ini:

1. Berdasarkan hasil dari Critical to Quality, didapatkan tiga jenis defect kaca lembaran LNFL yaitu cullet defect dengan persentase $45.6 \%$, chipping defect dengan persentase $31.0 \%$, dan bubble defect dengan persentase $17.0 \%$.

2. Berdasarkan Root Cause Analysis (RCA), diketahui akar permasalahan dari masing-masing jenis defect. Dari akar permasalahan yang ada, dianalisis untuk mendapatkan akar permasalahan kritis dari tiap jenis defect dengan metode FMEA. Berikut merupakan akar permasalahan kritis dari tiap jenis defect.

a. Cullet defect : Kurangnya pengetahuan operator terkait setting mesin cutting

b. Chipping defect : Kurangnya pengetahuan operator terkait setting mesin cutting

c. Bubble defect : Pengawasan yang kurang ketat terkait kondisi operasi dan peralatan

3. Alternatif solusi diberikan pada setiap akar permasalahan kritis.

a. Cullet defect: Selektif dalam merekrut operator mesin cutting dan pemberian training secara berkala

b. Chipping defect: Selektif dalam merekrut operator mesin cutting dan pemberian training secara berkala

c. Bubble defect: Pelaksanaan patrol mingguan, sosialisasi ulang dan pembuatan poster terkait barang-barang non besi, serta pemberian warna pada barang-barang non besi

Penentuan target perbaikan didapatkan dari salah satu expert di divisi produksi sehingga didapatkan perbandingan antara nilai DPMO dan sigma level eksisting dengan target perbaikan sebagai berikut. a. Kondisi Eksisting

- Nilai DPMO sebesar 16,434

- Sigma level sebesar 3.63 sigma

b. Kondisi Target Perbaikan

- Nilai DPMO sebesar 9,022

- Sigma level sebesar 3.86 sigma

Jadi, diharapkan terjadi peningkatan sebesar 0.23 sigma.

\section{DAFTAR PUSTAKA}

[1] P. Keller and T. Pzydek, The Six Sigma Handbook, 4th ed. McGraw-Hill Professional Publishing, 2010.

[2] D. C. Montgomery, Introduction to Statistical Quality Control, 7th ed. John Wiley and Sons, Inc, 2012.

[3] isixsigma, "Kalkulator Six Sigma," 2017. [Online]. Available: $\mathrm{http}: / /$ www.isixsigma.com.

[4] D. Mann, Creating a Lean Culture. USA: CRC Press, 2010.

[5] M. L. Singgih and Irmia, "Pengukuran dan Peningkatan Pelayanan Perbaikan Gangguan Telepon pada PT X dengan Pendekatan Six Sigma," 2007.

[6] R. E. McDermott, R. J. Mikulak, and M. R. Beauregard, "The Basics of FMEA,” 2009. 